\title{
WHY DO AMERICANS AND GERMANS WORK DIFFERENT HOURS?
}

\author{
Linda Bell and Richard Freeman
}

The simple fact is that (Germany is) ... organized like a collective leisure park.

(Chancellor Kohl, quoted in Financial Times Survey on Germany,

October 25, 1993: 1)

Americans are crazy workaholics ... because they haven't a clue how to live.

(sophisticated Berliner, quoted in coffee shop)

At the outset of the 1990's German workers worked fewer hours over the year than did workers in the United States and in most OECD European countries. Several pathbreaking IG Metall contracts in the 1980's and 1990 will lower normal German work hours in the next several years ${ }^{1}$ unless Germany alters its policies along lines laid out in the Rexrodt Report. ${ }^{2}$ On the other hand, it is difficult to see any factors reducing work hours in the United States.

The difference between the hours worked by Americans and by Germans-that places the U.S. second to Japan in time worked in the OECD ${ }^{3}$ and that makes Germany a "collective leisure park," according to Chancellor Kohl -is a recent phenomenon. In the not so distant past the United States led the developed world in reductions in hours worked. Shorter working time was a major goal of American labor since the turn of the century. The U.S. was among the earliest countries to establish the eight-hour-five day workweek. The U.S. expanded vacation time after World War II. In the 1950's and early 1960's Americans worked considerably fewer hours than Germans and other Europeans. Not until the 1980's did German hours worked fall below American hours worked. ${ }^{4}$

What has caused the gap berween the average hours worked by Americans and the hours worked by Germans in recent years? Is the difference a matter of demographics - such as differences in the age, family, or educational composition of the populations? Does the gap reflect labor supply responses to incentives? What is the role of institutions-Germany's stronger unions, works councils (which have codetermination rights over work hours), or legal regulations-in the gap in time worked? Finally, are differences in hours worked due to different tastes for work caused perhaps by different norms of effort and relative pay? 


\section{LINDA BELL, RICHARD FREEMAN}

This chapter examines these questions using microdata from the International Social Survey Program, the May 1985 Current Population Survey, the 1989 EEC Ad Hoc Survey of the Labor Market, and other sources. In contrast to studies that deal strictly with observable hours of work, we also examine preferences for work schedules as revealed in surveys of attitudes. We begin by describing the recent hours gap between Americans and Germans using a variety of sources of data. We then contrast preferences for work versus leisure between workers in the two populations and compare these preferences with OECD European country norms. We find that although American workers work more hours than do workers in Germany and other European countries they are still more likely to prefer additional hours than are German and other European workers. Similarly, although Germans work fewer hours than Americans, they are more predisposed to further reductions in hours than are American workers and workers in other European countries. The data suggest that while Americans are unique in the sense of working long hours and desiring longer hours of work, Germans are also unique in working relatively few hours and desiring less work. We cannot explain the U.S.-German difference in hours worked and preferences for work by standard labor supply factors. We hypothesize that the difference may partially refiect more subtle supply behavior in the form of responses to differences in labor market inequality, and present some suggestive evidence that, in fact, people in settings with greater earnings inequality work more than those in settings with less inequality.

\section{HOURS WORKED IN THE U.S. AND GERMANY}

Line 1 of Table 5.1 presents OECD estimates of annual hours worked of American and German workers that constitutes the basic "fact" that motivates this study. The In differential between the two estimates suggests that in 1990 German employees in 1990 worked approximately 10 percent fewer annual hours than did their American counterparts. While substantial, this estimate understates the full difference in market activity between the two populations because the ratio of employees to working age population also differs. In 1990, 86 percent of American men participated in the work force compared to 81 percent of German men, while 68 percent of American women were in the work force compared to 57 percent of German women. ${ }^{5}$ Adjusting for differences in the employment to population ratios in the two countries (line 2) produces a differential in working hours per adult of 0.19 in points. Although a complete accounting of why Americans work more than Germans would explore differences in work force participation as well as in the hours worked of employed persons, we concentrate on the latter issue, or in explaining the roughly 10 percent differential between annual hours worked by employed persons in the two countries.

To examine the factors that may underlie the difference in hours worked per employee we use the following identity:

$$
A H=(H+E H) / H \times(H) \times(D) \times W W
$$




\begin{tabular}{lccc}
\hline & U.S. & Germany & In Differential \\
\hline Part A. Hours Worked per Year & & & \\
1. Annual Hours Worked & 1750 & 1589.00 & 0.10 \\
2. Employment/Population (15-64) & 0.73 & 0.66 & 0.09 \\
3. Annual Hours per Adult & 1272 & 1047 & 0.19 \\
4. Vacation Time in 5-day weeks & 2.5 & 6.2 & \\
5. Holiday Time in 5-day weeks & 2.0 & 2.4 & \\
6. Vacation and Holiday/52 & 0.09 & 0.17 & 0.08 \\
7. Vacation and Holiday Share of Payroll & 0.08 & 0.15 & \\
8. Hours Per Working Week & 38 & 36 & 0.05 \\
9. Annual Hours Worked (52*(8)*1-(6)]) & 1798 & 1551 & 0.15 \\
\hline
\end{tabular}

Part B. Work Schedules

10. Distribution of Hours/Week $<24$

$25-29$

$30-34$

$35-40$

$41-45$

$\begin{array}{rr}12 & 11 \\ 4 & 2 \\ 5 & 3 \\ 7 & 31 \\ 37 & 29 \\ 30 & 17\end{array}$

$>45$

11. Days Worked Per Week

$4.9 \quad 4.8$

12. Distribution of Days

Usually Work Saturday

Usually Work Sunday

Work 7 days a week

13. Work Shifts

On shift schedule

Night work

$\begin{array}{rr}24 & 12 \\ 12 & 4 \\ 3 & 1\end{array}$

14. Moonlighting (2nd job)

Usually work a second job

Sometimes work a second job

$22 \quad 8$

$13 \quad 8$

Sources: German Figures, lines 1-3, OECD; lines 4-7, Owen, 1989, table 2; lines 8, 11-13 EEC, table 21; lines 10, 14 ISSP

U.S. figures, lines 1-3, OECD; lines 4-7, Owen, 1988, lines 8, 11-13, Shank; lines 10,14 ISSP

Nore: 'Approximare figures.

This divides $A H$, annual hours worked per employed person into:

$1 H$, hours worked per day on a job, which both countries legislate;

$2 \mathrm{EH}$, extra hours worked per day - overtime at a given job or moonlighting on a second job;

$3 D$, days worked per week, which depends on whether workers are full-time or part-time and the prevalence of work during weekends; and

$4 W W$, weeks worked per year, which are largely determined by the extent of 
vacation and holiday days but are also affected by unemployment and the prevalence of contingent employment as well.

Unfortunately, microdata are not available from a single data source for all of the components of equation (1) above. Thus, we estimate the components of (1) from diverse data sources that do not necessarily add to the OECD differentials on line 1.

Lines 4-7 of Table 5.1 summarize differences in annual work hours in the two countries that arise from differences in vacation and holiday time. Consistent with analyses of working time that stress the importance of vacation and holiday time as the major cause of country differences in annual work time (Owen 1986, 1988), the data suggest that such differences are the primary factor behind greater American work hours. Differences in weeks of vacation and holiday time translate into a 17 percent reduction in worktime in Germany compared to 9 percent reduction of worktime in the United States, and therefore contributes $0.08 \mathrm{ln}$ points to the annual hours gap between the two countries.

In addition to the sizable differences in weeks worked per year between American and German workers there are also differences in hours worked per day and days worked per week in the two countries. For example, estimates of hours worked per week from the CPS (U.S.) and EEC (Germany) show that Americans average 38 hours compared to 36 hours for Germans (line 8) -a 0.05 ln point differential. Combining these numbers and the vacation and holiday figures in line 8 gives an estimated annual hours worked for Germans of 1,554, which is a bit below the OECD figures, and an estimate for the U.S. of 1,798 , which is a bit above the OECD figure, and suggests an $\ln$ differential of 0.15 in working hours over the year.

The bottom panel of Table 5.1 examines in greater detail differences in work schedules between Americans and Germans using data for the U.S. from the March 1985 CPS and 1989 ISSP, and data for Germany from the 1989 EEC Study and ISSP. Line 10 shows that the distributions of hours per week differ substantially between the two countries, and suggests that differences in the average hours worked per week are not due primarily to Germans working less than the standard weekly hours but to Americans working more hours. Line 11 shows that although both countries have institutionalized the basic 5-day working week, Americans put in a bit more time than their German counterparts ( 4.9 days per week versus 4.8 days for Germans). The distribution of days (line 12) tells a similar story: Americans are twice as likely to work Saturdays, three times as likely to work Sundays, and three times as likely to work 7 days a week as are Germans. Finally, Americans are also more likely to do shift work and night work; and are more likely to moonlight with second jobs than are German workers. In sum, the message of Table 5.1 is that along all dimensions of work time, Americans work more than Germans.

Has the hours worked gap among employees "always" existed or is it a relatively recent phenomenon? The evidence in Figure 5.1 shows that the gap is not a longstanding historical pattern, although the exact timing of the crossover in hours worked is debatable. Maddison's estimates in the upper panel show that from 1870 to 1929 Americans worked about the same number of hours as Germans; but that 
U.S. vs. Germany, 1870-1984

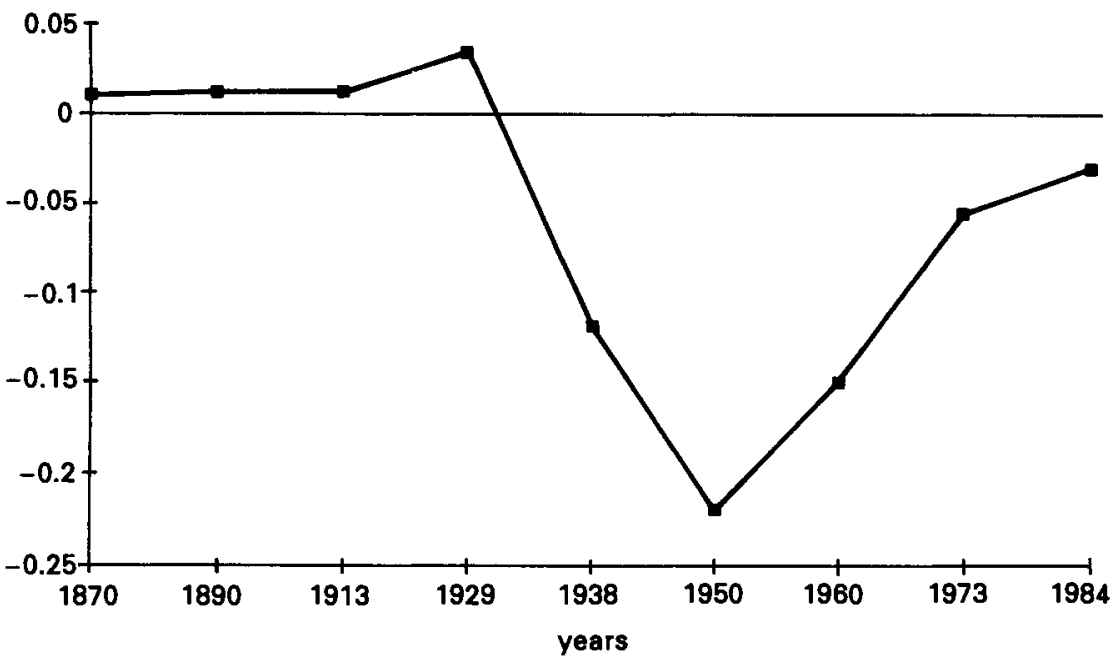

U.S. vs. Germany, 1970-1990

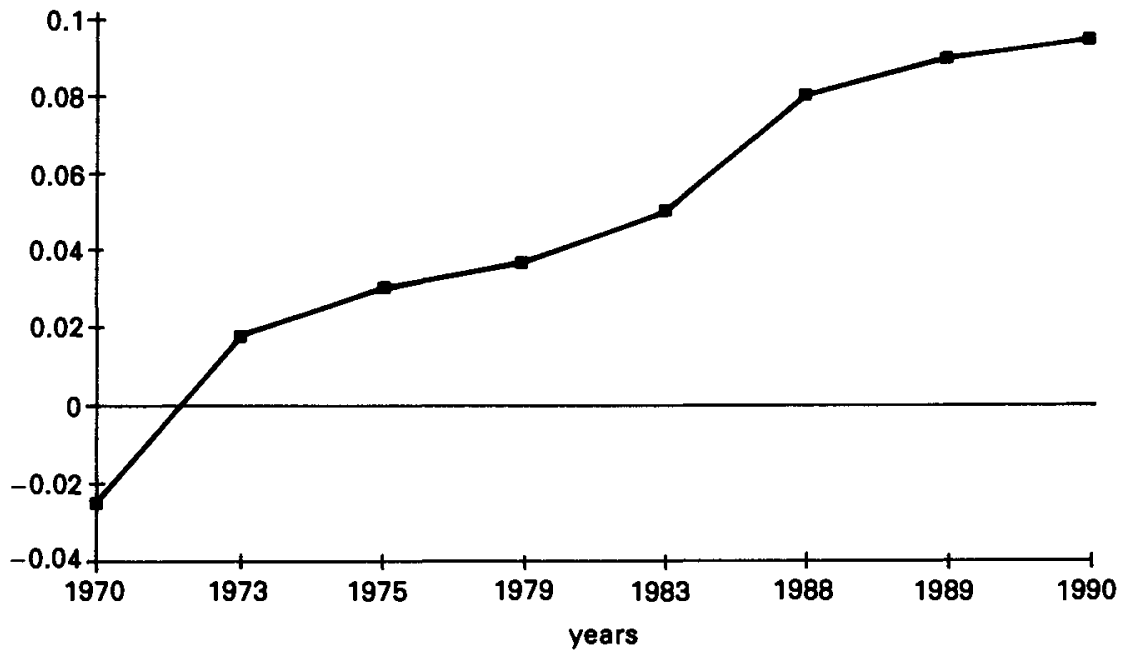

Figure 5.1 Ln Differential in Annual Hours Worked per Employee, U.S. vs. Germany (1870-1984; 1970-1990)

Sources. Top Panel: Maddison, A. (1987) "Growth and Slowdown in Advanced Capitalist Economies," Joumal of Economic Literature, June: 686. Bottom Panel: OECD Economic Outlook, 1992 
they worked less hours from the 1930's and through 1984, with the gap rising from 1929 to 1950 and then declining. The OECD data in the bottom panel show Americans working fewer hours in 1970 but more hours by 1973, and an increasing gap thereafter. Evidence from Owen $(1986,1989,1990)$ and the ISSP estimates suggest that U.S hours surpassed German hours worked by the early 1980 's, at least, consistent with the OECD figures. Indeed, while in the 1970's and 1980 's the U.S. standard workweek did not change, weeks worked per year seem to have increased. Owen (1988: 43) estimates that from 1975 to 1986 the full-week vacation time of nonagricultural wage and salary workers in the U.S. fell by 13 percent and the BLS reports a drop in paid holidays and vacations from 1980 to 1989 in medium and large firms (BLS 1990). By contrast, Germans continued to reduce their work time, lowering the standard hours worked per day (from 8.1 in 1960 to 7.9 in 1986), reducing days per week (from 5.5 in 1960 to 5.0 in 1970), and adding more vacation days (Owen 1989, Table 2). Since the employment to population ratio rose in the U.S. relative to Germany from the early 1970's to the 1980's, while unemployment rates in the U.S. fell relative to those in Germany, measures of time worked per adult strengthen the conclusion that the longer U.S. hours worked is a relatively recent phenomenon. ${ }^{6}$ The observed shift over time in who works more makes any "cultural" explanation of the 1990's U.S.-German gap dubious to us.

\section{A Comparison with Hours Worked in the OECD}

Table 5.2 presents estimates on hours worked for full-time manufacturing workers in European OECD countries and the United States using data from yet another source, the Federation of German Employers Associations (BDA). According to the BDA figures, full-time manufacturing workers in the United States and Germany are "outliers" in the hours they work. Column 1 shows that U.S. manufacturing workers work 130 hours more per year than the average number of hours worked in European OECD countries (column 1). Similarly, German workers work 131 hours fewer than the average European OECD worker annually (column 1). Columns 2-4 of the table show that in terms of vacation and holiday time, U.S. workers have below average time off and German workers have above average time off when compared to their European counterparts. Finally, column 5 of the table shows that full-time U.S. manufacturing workers work 0.7 hours more per week and German workers about 1.7 hours fewer per week, than the typical OECD European worker. ${ }^{7,8}$

In sum, a multicountry perspective on the U.S-German hours worked gap suggests that both countries are extreme in their working hours. U.S. workers work more on average than workers in most European countries. German workers work less. 
Table 5.2 Hours Worked by Full-time Manufacturing Workers ${ }^{2}$ in OECD Countries, 1990

\begin{tabular}{|c|c|c|c|c|c|}
\hline & Annual Hours & $\begin{array}{c}\text { (2) } \\
\text { Vacation Time in } \\
\text { 5-day Weeks }\end{array}$ & $\begin{array}{c}\text { (3) } \\
\text { Holiday Time in } \\
\text { 5-day Weeks }\end{array}$ & $\begin{array}{c}\text { (4) } \\
\text { Vacation and } \\
\text { Holiday } \\
\text { Weeks } / 52\end{array}$ & $\begin{array}{c}\text { (5) } \\
\text { Hours per } \\
\text { Working Week }\end{array}$ \\
\hline Austria & 1,714 & 5.3 & 2.5 & 0.15 & 38.6 \\
\hline Belgium & 1,737 & 4.0 & 2.2 & 0.12 & 37.8 \\
\hline Denmark & 1,672 & 5.0 & 2.0 & 0.13 & 37.0 \\
\hline Finland & 1,716 & 8.0 & 1.8 & 0.19 & 40.0 \\
\hline France & 1,763 & 5.0 & 2.0 & 0.13 & 39.0 \\
\hline Germany & 1,643 & 6.0 & 2.5 & 0.16 & 37.6 \\
\hline Greece & 1,840 & 4.4 & 1.8 & 0.12 & 40.0 \\
\hline Ireland & 1,810 & 4.2 & 1.6 & 0.11 & 39.0 \\
\hline Italy & 1,764 & 6.3 & 1.8 & 0.16 & 40.0 \\
\hline Luxembourg & 1,792 & 5.4 & 2.0 & 0.14 & 40.0 \\
\hline Netherlands & 1,709 & 6.9 & 1.4 & 0.16 & 38.9 \\
\hline Norway & 1,718 & 4.2 & 2.2 & 0.12 & 37.5 \\
\hline Portugal & 1,935 & 4.4 & 2.8 & 0.14 & 43.0 \\
\hline Spain & 1,790 & 4.7 & 2.8 & 0.14 & 40.0 \\
\hline Sweden & 1,784 & 5.4 & 2.2 & 0.15 & 40.0 \\
\hline Switzerland & 1,864 & 4.7 & 1.6 & 0.12 & 40.6 \\
\hline U.K. & 1,769 & 5.0 & 1.6 & 0.13 & 38.8 \\
\hline United States & 1,904 & 2.4 & 2.2 & 0.09 & 40.0 \\
\hline Average & 1,774 & 5.1 & 2.1 & 0.14 & 39.3 \\
\hline U.S.-Avg & 130 & -2.7 & 0.1 & -0.05 & 0.7 \\
\hline Germany-Avg & -131 & 0.9 & 0.4 & 0.02 & -1.7 \\
\hline
\end{tabular}

Sources: Federation of German Employers' Association (BDA) using in formation from European sister organizations. Supplied by Bureau of Labor Statistics, Department of International Labor Statistics

Nozes: 'Data do not include short-time or part-time workers. Unweighted averages are from countries as listed.

\section{Hours Worked in the ISSP}

To obtain data on American and German hours worked from a comparable micro survey we turn to the 1989 International Social Survey Program (ISSP). The ISSP is a program of cross-national collaboration carried out by research institutes that conduct annual surveys of social artitudes and values. The virtue of the survey is that it seeks to ask similar questions in identical form in the participating nations. In 1989 the surveys focused on work, with numerous questions exploring attitudes toward work time and effort. Although the ISSP would seem the perfect data source for a study of this sort it is not ideal for several reasons. First, questions on hours worked are limited to weekly hours, and exclude vacation or holiday time. The survey does not therefore permit us to evaluate difference in hours worked per day or days worked per week in the two countries. Second, earnings relate to yearly 


\section{LINDA BELL, RICHARD FREEMAN}

earnings rather than to hourly pay. Third, there is no useful measure of assets or wealth in the study. Fourth, despite the attempt for comparability, not every question is phrased the same way across countries, and different countries do not always ask the same questions in any given year. Despite these limitations, the ISSP is the best available cross-country data set for our purposes and provides us with additional information on work preferences.

Table 5.3 presents estimates of ISSP-based hours worked by American and German workers from 1985 to $1989 .^{9}$ While the mean level of hours exceeds that shown in line 8 of table 1 and column 7 of Table 5.2, the gap in hours is a comparable 0.05 In differential for all workers. However, the figures for all workers

Table 5.3 Average Hours Worked by Germans and Americans

\begin{tabular}{|c|c|c|c|c|c|c|}
\hline & 1985 & 1986 & 1987 & 1988 & 1989 & 1989 (Adjusted) \\
\hline \multicolumn{7}{|l|}{ All } \\
\hline Germany & 43.63 & 41.57 & 41.19 & 40.71 & 39.19 & 39.78 \\
\hline U.S. & 42.45 & 41.58 & 40.93 & 41.22 & 41.43 & 41.43 \\
\hline Difference & -1.18 & 0.01 & -0.26 & -0.51 & 2.24 & 1.65 \\
\hline ln Difference & -0.03 & 0.00 & -0.01 & 0.01 & 0.06 & 0.04 \\
\hline \multicolumn{7}{|l|}{ Male } \\
\hline Germany & 46.17 & 44.78 & 43.59 & 44.06 & 42.74 & 43.31 \\
\hline U.S. & 44.72 & 44.90 & 43.63 & 44.94 & 45.32 & 45.32 \\
\hline Difference & -1.45 & 0.12 & 0.04 & 0.88 & 2.58 & 2.01 \\
\hline In Difference & -0.03 & 0.00 & 0.00 & 0.02 & 0.06 & 0.05 \\
\hline \multicolumn{7}{|l|}{ Female } \\
\hline Germany & 38.68 & 36.16 & 39.17 & 35.48 & 34.20 & 34.80 \\
\hline U.S. & 38.06 & 37.76 & 38.24 & 37.49 & 37.17 & 37.17 \\
\hline Difference & -0.60 & 1.60 & 0.93 & 2.01 & 2.97 & 2.37 \\
\hline In Difference & -0.02 & 0.04 & -0.02 & 0.06 & 0.08 & 0.07 \\
\hline \multicolumn{7}{|l|}{$35+$ hours } \\
\hline Germany & 47.11 & 44.52 & 44.04 & 43.77 & 42.59 & 43.06 \\
\hline U.S. & 47.14 & 46.38 & 46.12 & 46.07 & 46.71 & 46.71 \\
\hline Difference & 0.03 & 1.86 & 2.08 & 2.30 & 4.12 & 3.65 \\
\hline In Difference & 0.00 & 0.04 & 0.05 & 0.05 & 0.09 & 0.08 \\
\hline \multicolumn{7}{|l|}{ Union } \\
\hline Germany & 42.34 & 40.90 & 40.31 & 40.74 & 39.46 & 40.16 \\
\hline U.S. & 43.25 & 42.85 & 42.95 & 43.31 & 40.16 & 40.16 \\
\hline Difference & 0.91 & 1.95 & 2.64 & 2.57 & 0.70 & 0.00 \\
\hline In Difference & 0.02 & 0.05 & 0.06 & 0.06 & 0.02 & 0.00 \\
\hline \multicolumn{7}{|l|}{ Self-Employed } \\
\hline Germany & 56.55 & 51.83 & 50.95 & 52.75 & 47.55 & 48.68 \\
\hline U.S. & 44.48 & 42.86 & 41.39 & 42.29 & 40.10 & 40.10 \\
\hline Difference & -12.07 & -8.97 & -9.56 & -10.46 & -7.45 & -8.58 \\
\hline In Difference & -0.24 & -0.19 & -0.21 & -0.22 & -0.17 & -0.19 \\
\hline
\end{tabular}

Source. ISSP 1985-1989

Note:

${ }^{2}$ Hours adjusted for second job hours for German workers to account for differences in the hours worked question in the two countries. 
mask considerable differences in hours worked for key demographic groups. Because 58 percent of German workers in the ISSP were male versus 52 percent of American workers and 83 percent of German workers are full-time versus 79 percent of American workers, the aggregate hours figures understate the difference in work time among demographic groups. Differences in hours worked among both men and women exceed those for the aggregate (lines 2 and 3). And when we look only at full-time workers, the gap in hours nearly doubles, to 4 hours worked per week or 0.09 In points. ${ }^{10}$ Only among the self-employed is the difference reversed. ${ }^{11}$

In sum, there is a sizable hours worked difference between Germans and Americans, that is a relatively recent phenomenon, and that reflects both the relatively long hours worked by Americans and the relatively short hours worked by Germans.

\section{PREFERENCES FOR HOURS WORKED}

How much do Germans and Americans want to work? Would Germans prefer to work more hours? Do Americans want reduced hours? Which of the two populations seems closer to attaining its preferred number of hours worked? While economists often eschew self-reports of preferences, the difficulties in standard labor supply analysis suggest that evidence on preferences can illuminate hours worked issues.

Table 5.4 tabulates the responses to the key question about preferences for hours worked by American, German, and other European OECD workers on the ISSP:

Think of the number of hours you work and the money you earn in your main job, including regular overtimi. If you only had one of these three choices, which of the following would you prefer: work longer hours and earn more money; work the same number of hours and earn the same money; work fewer hours and earn less money.

The results in Part A show a striking U.S.-German difference. Although the majority of both populations are "sarisfied" with their hours of work, a disproportionately large number of Americans want to work more hours than want to work fewer hours ( 33 percent versus 6 percent in the first panel) while the proportions of Germans who want to work more hours is roughly equal to the proportion who want to work fewer hours (14 percent versus 10 percent). Strong differences in preferences for work are also shown for males, union workers, and self-employed, with U.S. workers preferring relatively longer hours, and German workers relatively fewer hours, and with Germans more satisfied with their actual hours worked.

The results in Part B show a similar difference at all levels of actual work. Even among workers purting in greater than 45 hours per week significantly more Americans want to work longer than want to work fewer hours. ${ }^{12}$

Is the U.S.-German gap in preferences due to the fact that U.S. workers are more work minded than workers elsewhere or to the fact that Germans are less work-minded? Comparison with the OECD averages (weighted by sample size) in 
LINDA BELL, RICHARD FREEMAN

Table 5.4 Feelings about Work Effort (\% of workers with preference)

(I)

(2)

(3)

More Hours/More Pay Same Hours/Same Pay Fewer Hours/Less Pay

Part A: Demographic Differences

All

U.S.

32.67

13.50

61.83

5.51

German

$-19.16$

Male

U.S.

37.18

German

12.32

Difference

24.86

Female

U.S.

27.54

German

Difference

15.16

12.38

Union

U.S.

38.55

German

11.54

Difference

27.02

Self Employed

U.S.

36.78

German

14.81

Difference

21.97

76.41

10.09

$-14.58 \quad-4.58$

57.18

5.65

$77.13 \quad 10.56$

$-19.95 \quad-4.91$

67.11

75.41

$-8.30$

5.35

9.43

$-4.08$

56.63

78.57

4.82

9.89

$-21.94$

$-5.07$

50.57

70.37

12.64

14.81

$-19.80$

$-2.17$

Parr B: Hours Worked Differences

1-10 hours

U.S.

German

11-20 hours

U.S.

German

21-30 hours

U.S.

German

31-35 hours

U.S.

German

35-40 hours

U.S.

German

41-45 hours

U.S.

German

46-50 hours

U.S.

German

$50+$ hours

U.S.

German
61.54

33.33

28.26

12.50

39.71

25.71

28.57

19.05

27.33

9.83

29.33

17.57

39.33

17.65

37.59

15.91
38.46

33.33

63.04

82.14

54.41

68.57

69.05

76.19

70.00

81.69

64.00

75.68

52.81

64.71

52.48

59.09
0.00

33.33

8.70

5.36

5.88

5.71

2.38

4.76

2.67

8.47

6.67

6.76

7.87

17.65

9.93

25.00

(continued) 
(3) More Hours/More Pay Same Hours/Same Pay Fewer Hours/Less Pay

Part C: OECD Comparisons

$\begin{array}{lrrr}\text { United States } & 32.67 & 61.83 & 5.51 \\ \text { Germany } & 13.50 & 76.41 & 10.09 \\ \text { United Kingdom } & 23.77 & 68.05 & 8.17 \\ \text { Austria } & 22.59 & 71.53 & 5.88 \\ \text { Netherlands } & 17.54 & 70.16 & 12.29 \\ \text { Italy } & 31.03 & 62.43 & 6.53 \\ \text { Ireland } & 30.37 & 64.64 & 4.99 \\ \text { Northern Ireland } & 26.85 & 67.59 & 5.56 \\ \text { Norway } & 24.36 & 68.70 & 6.93 \\ \text { U.S.-Wt. Avg. } & 8.14 & -6.30 & -1.83 \\ \text { Germany-Wr. Avg. } & -11.03 & 8.28 & 2.75\end{array}$

Source. ISSP 1989

Note. Responses to the question asked of every working individual "Think of the number of hours you work and the money that you make in your main job, including regular overtime. If you had only one of three choices, which of the following would you prefer? (1) Work longer hours and earn more money; (2) Work the same number of hours and earn the same money; (3) Work fewer hours and earn less money"

Part $\mathrm{C}$ of the table shows that both statements are true. A far greater number of U.S. workers prefer to work longer hours than the European norm, and fewer American workers prefer shorter hours. Similarly, fewer Germans desire to work more hours and more Germans chose to work fewer hours than is the average throughout the OECD countries surveyed here.

Since the ISSP question specifically includes overtime pay, it is possible that the different answers across countries reflect responses to differences in the rate of overtime pay. For example, the overtime rate in the U.S. (1.5 times regular pay) exceeds the overtime rate in Germany (1.25 times regular pay), which ought to induce Americans to favor additional (or overtime) work to a greater extent than Germans. The fact that U.S. and German workers are "outliers" among OECD workers suggests that an overtime explanation for the difference is not likely. Moreover, the fact that self-employed workers in the U.S. and Germany show similar preferences as other workers in the countries also contravenes this view. Still, the explicit inclusion of overtime in the ISSP work preference question is a valid concern which we address more directly below.

What meaning should be attached to the finding that a disproportionate larger share of Americans wish to work more hours than they are currently working or to the fact that a substantial share of Germans would like to work fewer hours? In a static competitive market equilibrium with no adjustment costs or constraints all workers would work to equate their marginal rate of substitution of work for leisure and the wage they receive, and would report no desire to change their 
hours of work. In a more dynamic setting (random shocks that disturb this static equilibrium) some workers would want to work more and some would want to work less, but the numbers in each category would presumably be the same. Viewed in this way, the data in Panel C suggest that the more institutionalized German market produces a distribution of working hours and pay that is nearer to equilibrium (the largest proportion of workers chose to work the same hours and roughly equal numbers report they wish more and less hours) whereas the flexible decentralized American labor market is in greater disequilibrium (a smaller proportion are satisfied with their hours and a disproportionate share want to work more hours) - failing to supply the amount of work desired by the population at the relevant pay, or alternatively generating unfulfillable demands for work hours.

\section{Corroborating Evidence on Preferences}

We have checked the reliability of the Table 5.3 difference in German and U.S. work preferences by examining the responses of workers on two other surveys that ask comparable questions.

The May 1985 CPS contained detailed questions on work scheduling and preferences for hours worked among U.S. workers, iding the following question:

If you had a choice would you prefer to work: (1) the same number of hours and earn the same money; (2) fewer hours at the same rate of pay and earn less money; (3) more hours at the same rate of pay and earn more money?

Since the CPS asks about usual hourly earnings (exclusive of overtime), this question asks for work preferences at one's normal pay. Table 5.5 gives our tabulations of the responses of American workers. The pattern corroborates the pattern in the ISSP. While a majority of American workers are satisfied with their hours worked, many more want to work more hours than want to work fewer hours at the going rate. This is true for men and women, for the self-employed, and for union workers. When the responses are disaggregated by actual time worked, moreover, we replicate Shank's (1986) finding that the proportion wanting to work more hours falls with hours worked. ${ }^{13,14}$

The 1989 EEC survey of worktime preferences asked the following question that provide comparable information about German workers:

Assuming that your present hourly rate remained unchanged, would you like to work less, as long, or longer?

This question abstracts from issues of overtime pay and is therefore comparable to the 1985 CPS question. The responses, tabulated in part A of Table 5.6, diverge noticeably from the ISSP figures for Germans. Instead of a roughly symmetric distribution around current work time, many more Germans prefer less work time to more work time. 
Table 5.5 Choices over Hours Worked and Pay, U.S. Employed, 1985 CPS Supplement (\% of Workers with Preference)

(1)

(2)

(3)

More Hours/More Pay Same Hours/Same Pay Fewer Hours/Less Pay

Part A: Demographic Characteristics

\begin{tabular}{|c|c|c|c|}
\hline $\begin{array}{l}\text { All Workers } \\
\qquad(\mathrm{n}=47,054)\end{array}$ & 27.0 & 65.2 & 7.8 \\
\hline $\begin{array}{l}\text { Male Workers } \\
\quad(\mathrm{n}=24,066)\end{array}$ & 29.1 & 64.5 & 6.4 \\
\hline $\begin{array}{l}\text { Female Workers } \\
\qquad(\mathrm{n}=22,993)\end{array}$ & 24.7 & 65.9 & .4 \\
\hline $\begin{array}{l}\text { Union Workers } \\
\qquad(\mathrm{n}=1,978)\end{array}$ & 22.2 & 69.3 & 8.5 \\
\hline $\begin{array}{l}\text { Self-Employed } \\
\quad(n=3,889)\end{array}$ & 25.4 & 65.3 & \\
\hline \multicolumn{4}{|c|}{ Part B: Hours Worked Characteristics } \\
\hline $\begin{array}{l}\text { Working }<35 \text { Hours } \\
\quad(\mathbf{n}=8,502)\end{array}$ & 42.6 & 52.4 & \\
\hline $\begin{array}{l}\text { Working } 35+\text { Hours } \\
(\mathrm{n}=38,552)\end{array}$ & 23.5 & 68.0 & 8.5 \\
\hline $\begin{array}{l}\text { Working 35-39 Hours } \\
(\mathrm{n}=3,751)\end{array}$ & 29.0 & 63.4 & 7 \\
\hline $\begin{array}{l}\text { Working } 40-49 \text { Hours } \\
\quad(\mathrm{n}=28,312)\end{array}$ & 23.8 & 68.9 & \\
\hline $\begin{array}{l}\text { Working } 50-59 \text { Hours } \\
\quad(n=3,957)\end{array}$ & 20.7 & 66.4 & \\
\hline $\begin{array}{l}\text { Working } 60+\text { Hours } \\
\quad(n=2,532)\end{array}$ & 16.2 & 67.3 & \\
\hline
\end{tabular}

Source: CPS May 1985 Supplement on Work Schedules and Dual Job Holders

Note: Responses to the following question: "If you had a choice would you prefer to work: (1) the same number of hours and earn the same money; (2) fewer hours at the same rate of pay and earn less money, or; (3) more hours at the same rate of pay and earn more money?"

A follow-up to this question on the $1989 \mathrm{EEC}$ asked workers to indicate how many hours per week they actually preferred to work. Part B of Table 5.6 contrasts this response to actual hours worked, and shows that Germans want to reduce hours from 35-40 to 30-34, with a resultant average gap between actual and desired hours of 2 hours.

A second question on the EEC relevant for determining work preferences asked workers to chose between a pay increase for the same amount of work or a work hours decrease for the same amount of pay worded as follows:

If the choice were offered in the next wage round between an increase in pay for the same hours of work and shorter working time for the same pay you get now, which would you prefer? 
Table 5.6 EEC Survey Evidence on German Preferred Working Hours

Part A

Percentage of Workers Preferring Less, the Same, or Longer Working Hours at the Same Rate of Pay

\begin{tabular}{lrrrrrr} 
& All & Men & Women & $<30$ & $30-49$ & $>49$ \\
\hline Work Less & 38 & 41 & 35 & 30 & 37 & 36 \\
Work As Long & 55 & 54 & 55 & 58 & 57 & 57 \\
Work More & 4 & 4 & 4 & 11 & 4 & 4 \\
\hline
\end{tabular}

Part $B$

Distribution of Desired and Actual Working Hours

\begin{tabular}{lcccccccc} 
& Average & $<20$ & $20-24$ & $25-29$ & $30-34$ & $35-40$ & $41-45$ & $45+$ \\
\hline Actual Hours & 36 & 3 & 5 & 5 & 7 & 71 & 3 & 6 \\
Desired Hours & 34 & 3 & 7 & 7 & 19 & 55 & 5 & 3 \\
\hline
\end{tabular}

Part C

If the Choice Were Offered in the Next Wage Round Between an Increase in Pay for the Same Hours of Work and Shorter Working Time for the Same Pay You Get Now, Which Would you Prefer?

\begin{tabular}{lcccccc} 
& All & Men & Women & $<30$ & $30-49$ & $>49$ \\
\hline Increase in Pay & 42 & 45 & 39 & 41 & 44 & 41 \\
Shorter Work Time & 44 & 44 & 45 & 45 & 44 & 44 \\
Undecided & 10 & 11 & 16 & 14 & 12 & 15 \\
\hline
\end{tabular}

Source. EEC, European Economy, March 1991 lines A, C, from table 22; line B from table 2

This is a difficult question to analyze because it specifies neither the increase in pay nor the added leisure time (although presumably respondents would consider marginal changes in pay and in working time). ${ }^{15}$ The results, given in Part $\mathrm{C}$ of Table 5.6, are close to the ISSP results for German workers, showing just about as many choosing higher income as less work time, a pattern to be expected if workers are considering modest changes from an equilibrium situation.

Figure 5.2 (opposite) Percentage of Workers Who Prefer to Work Fewer Hours, Same Hours, or More Hours at the Same Rate of Pay

Source. EEC (1991) European Economy, March: table 22. CPS: tabulated from May 1985 CPS Supplement

Note: The question in the EEC survey was: "Assuming that your present hourly rate remained unchanged, would you like to work less, as long, or longer?"

The question in the CPS survey was: "If you had a choice, would you prefer to work: the same number of hours and earn the same money; fewer hours at the same rate of pay and earn less money; more hours at the same rate of pay and earn more money?" 
WHY DO AMERICANS AND GERMANS WORK DIFFERENT HOURS?

Panel A: All

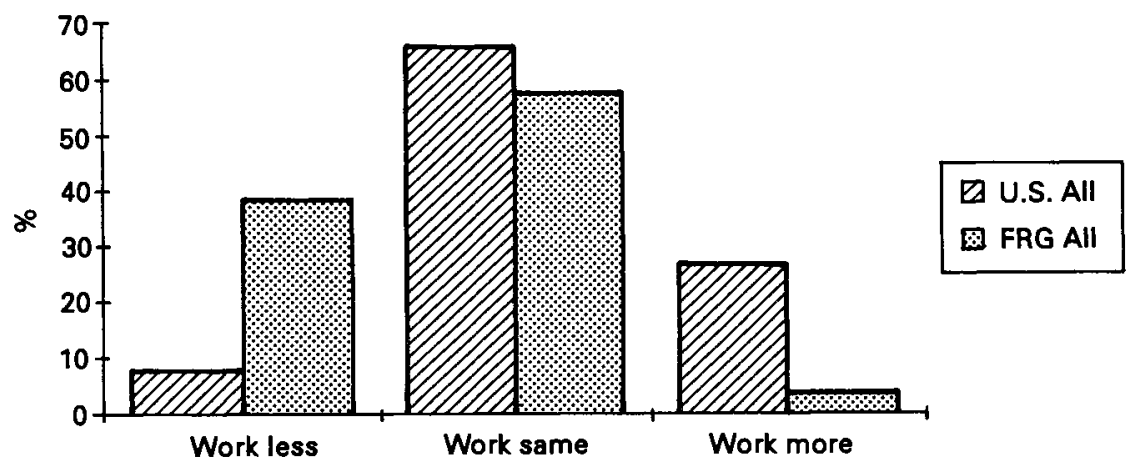

Panel B: Men

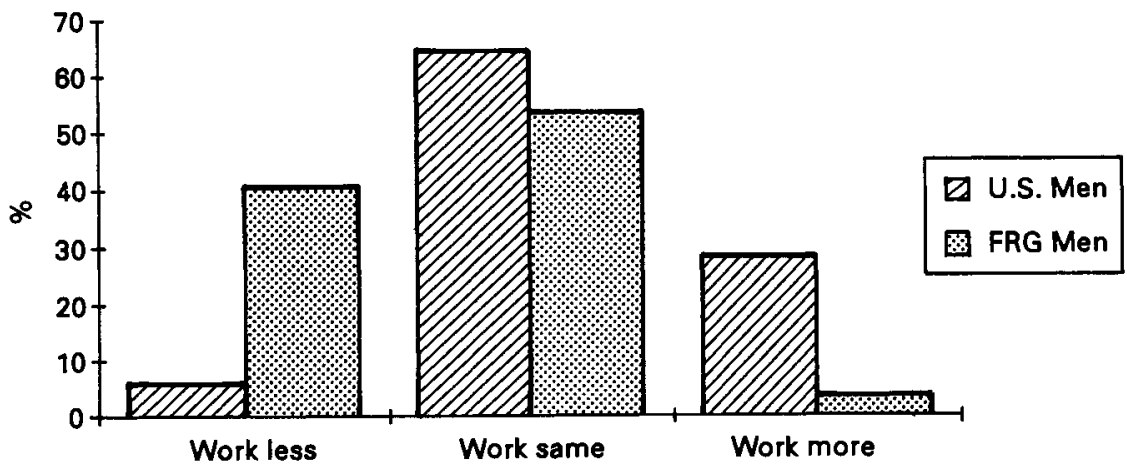

Panel C: Women

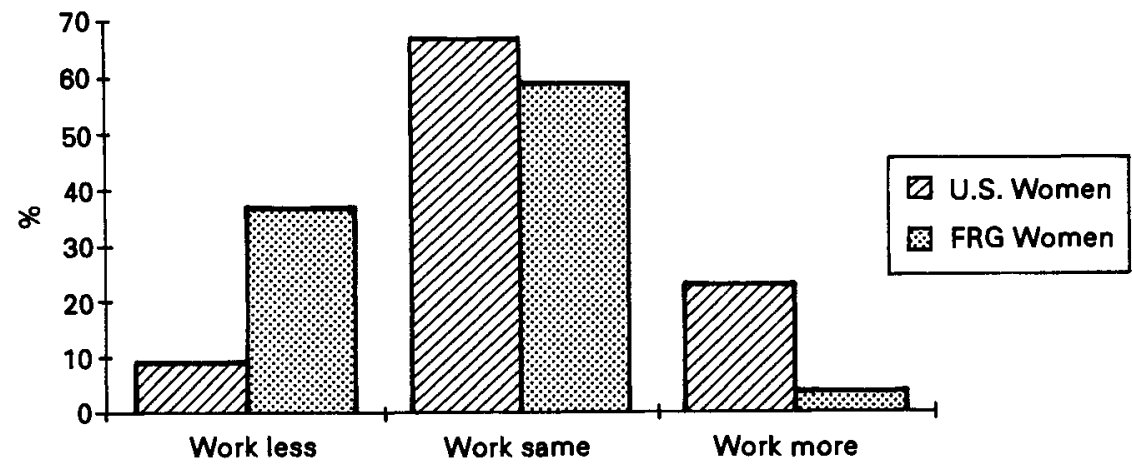


Figure 5.2 combines the results of the 1985 CPS Survey and 1989 EEC Survey for the U.S. and Germany. It shows extremely large differences in preferences between the two countries, which therefore strengthen the ISSP findings. The EEC evidence that Germans want to reduce work hours is, moreover, consistent with the trend in German working hours and the importance attached by German trade unions to a negotiated reduction of work hours in the furure.

Additional evidence that American and German workers have different preferences for work can be found in responses to other questions in the ISSP. For example, if Americans work more and want to work more than Germans and Europeans, they should give more work-oriented (pro-work) responses to other work-related questions as well. Table 5.7 shows that they do. Americans are more likely to report that they work hard "even if it interferes with the rest of (their) lives" than are Germans and other Europeans. Similarly, Germans are less likely to work hard "even if it interferes with the rest of their lives" than are their European and U.S. counterparts, and more likely to respond that they work "only as hard as they have to."

Finally, we offer the following short list of responses to different qualitative questions in the ISSP as corroborative evidence that American and Germans have markedly different attitudes about work. First, in response to a question asking if people work just for the money, 18 percent of Americans compared to 33 percent of Germans say they work just for the money. Second, asked if they would work without pay in their job, 67 percent of Americans said yes compared to 59 percent of Germans. Third, asked if leisure was important to them, 40 percent of Americans said yes compared to 74 percent of Germans.

All told, the impression from the ISSP is that American workers are more "into" work than are Germans and other European workers. In the same vein, Germans seem to be less into work than their European and U.S. counterparts. The puzzle is why large differences in actual hours worked have failed to quell American workaholicism and a German love of leisure.

\section{Preferences over Time}

If the U.S.-German difference in work preferences always held we would wonder if it reflected the particular (cultural) way Americans and Germans answer questions of this type, rendering the responses suspect to an economic analysis of the actual hours gap. If preferences changed over time, particularly in ways consistent with changes in hours worked, we would have greater confidence in believing the differences. Data reported by Katona et al. (1971) for German and American workers in the 1960's show that the gap in preferences, like the gap in actual hours, must have developed in the 1970's and 1980's. Specifically, they compare responses to the following question: ${ }^{16}$

Some people would like to work more hours a week if they could be paid for it. Others would prefer to work fewer hours per week even if they earned less. How do you feel about this? 
Table 5.7 Feelings Abour Work Effort: “How Hard Do You Work?” (\% with Preferences)

\begin{tabular}{|c|c|c|c|}
\hline & Only as Hard As Have To & $\begin{array}{c}\text { Hard But Not So } \\
\text { Interferes }\end{array}$ & Hard Even if it Interferes \\
\hline \multicolumn{4}{|l|}{ All Workers } \\
\hline Germany $(n=628)$ & 16.56 & 48.89 & 34.55 \\
\hline Great Britain $(n=720)$ & 5.69 & 36.94 & 57.36 \\
\hline United States $(\mathrm{n}=852)$ & 7.63 & 31.10 & 61.27 \\
\hline Austria $(n=869)$ & 9.67 & 43.50 & 46.84 \\
\hline Netherlands $(n=692)$ & 7.37 & 63.87 & 28.76 \\
\hline Italy $(n=581)$ & 7.75 & 43.72 & 48.54 \\
\hline Ireland $(n=477)$ & 10.48 & 38.99 & 50.52 \\
\hline$N$. Ireland $(n=333)$ & 7.81 & 32.73 & 59.46 \\
\hline Norway $(n=1070)$ & 12.24 & 43.74 & 44.02 \\
\hline U.S.-W't. Average & -1.96 & -11.89 & 13.86 \\
\hline German-Wt. Average & 6.97 & 5.90 & -12.86 \\
\hline \multicolumn{4}{|l|}{ Male Workers } \\
\hline Germany $(n=391)$ & 15.05 & 48.12 & 36.83 \\
\hline Great Britain $(n=450)$ & 5.37 & 33.76 & 60.87 \\
\hline United States $(n=504)$ & 8.22 & 28.44 & 63.33 \\
\hline Austria $(n=324)$ & 9.92 & 47.22 & 42.86 \\
\hline Netherlands $(n=443)$ & 8.80 & 62.53 & 28.67 \\
\hline Italy $(n=354)$ & 8.19 & 41.81 & 50.00 \\
\hline Ireland $(n=309)$ & 11.97 & 35.92 & 52.10 \\
\hline N. Ireland $(n=196)$ & 7.14 & 33.67 & 59.18 \\
\hline Norway $(n=598)$ & 13.55 & 43.81 & 42.64 \\
\hline U.S.-Ẃt. Average & -1.84 & -14.16 & 16.00 \\
\hline German-Wt. Average & 4.99 & 5.52 & -10.50 \\
\hline \multicolumn{4}{|l|}{ Female Workers } \\
\hline Germany $(n=249)$ & 18.75 & 50.00 & 31.25 \\
\hline Great Britain $(n=329)$ & 6.08 & 40.73 & 53.19 \\
\hline United States $(n=402)$ & 6.97 & 34.08 & 58.96 \\
\hline Austria $(n=365)$ & 9.32 & 38.36 & 52.33 \\
\hline Netherlands $(n=249)$ & 4.82 & 66.27 & 28.92 \\
\hline Italy $(n=227)$ & 7.05 & 46.70 & 46.26 \\
\hline Ireland $(n=168)$ & 7.74 & 44.64 & 47.62 \\
\hline N. Ireland $(n=137)$ & 8.76 & 31.39 & 59.85 \\
\hline Norway $(n=472)$ & 10.59 & 43.64 & 45.76 \\
\hline U.S.-Wt. Average & -1.97 & -9.45 & 11.44 \\
\hline German-Wt. Average & 9.81 & 6.47 & -15.27 \\
\hline \multicolumn{4}{|l|}{ Union Workers } \\
\hline Germany $(n=197)$ & 17.26 & 51.78 & 30.96 \\
\hline Great Britain $(n=274)$ & 5.47 & 40.15 & 54.38 \\
\hline United States $(n=89)$ & 5.62 & 32.58 & 61.80 \\
\hline Austria $(n=419)$ & 10.26 & 46.54 & 43.20 \\
\hline Netherlands $(n=199)$ & 8.54 & 64.32 & 27.14 \\
\hline Italy $(n=159)$ & 6.29 & 45.91 & 47.80 \\
\hline Ireland $(n=191)$ & 7.85 & 45.02 & 47.12 \\
\hline N. Ireland $(n=149)$ & 8.05 & 38.26 & 53.69 \\
\hline Norway $(n=606)$ & 12.54 & 44.22 & 43.23 \\
\hline U.S.-Wt. Average & -4.32 & -13.32 & 17.65 \\
\hline German-Wt. Average & 7.32 & 5.88 & -13.19 \\
\hline
\end{tabular}


Table 5.7 (Continued)

\begin{tabular}{lccc}
\hline & Only as Hard As Have To & $\begin{array}{c}\text { Hard But Not So } \\
\text { Interferes }\end{array}$ & Hard Even if it Interferes \\
\hline Self-Employed & & & \\
Germany $(\mathrm{n}=59)$ & 11.86 & 30.51 & 57.63 \\
Great Britain $(\mathrm{n}=84)$ & 3.57 & 28.57 & 67.86 \\
United States $(\mathrm{n}=100)$ & 6.00 & 25.00 & 69.00 \\
Austria $(\mathrm{n}=94)$ & 10.64 & 34.04 & 55.32 \\
Netherlands $(\mathrm{n}=40)$ & 5.00 & 52.50 & 42.50 \\
Iraly $(\mathrm{n}=175)$ & 9.14 & 32.57 & 58.29 \\
Ireland $(\mathrm{n}=96)$ & 17.71 & 21.88 & 60.42 \\
N. Ireland $(\mathrm{n}=50)$ & 10.00 & 16.00 & 74.00 \\
Norway $(\mathrm{n}=61)$ & 13.11 & 36.07 & 50.08 \\
U.S-Wt. Average & $-\mathbf{3 . 7 5}$ & $-\mathbf{5 . 0 4}$ & $\mathbf{8 . 7 9}$ \\
German-Wt. Average & $\mathbf{2 . 1 1}$ & $\mathbf{0 . 4 7}$ & $-\mathbf{2 . 5 8}$ \\
\hline
\end{tabular}

Source. ISSP data, 1989

Notes: Responses to the following question asked of every working individual. "Which of the following statements best describes your feelings about your job?: (1) I work only as hard as I have to; (2) I work hard, but not that it interferes with the rest of my life, and; (3) I make a point of doing the best work 1 can even if it somerimes interferes with the rest of my life."

American responses to the survey are similar to those in the ISSP and CPS surveys. Specifically, 34 percent of U.S. workers responded that they wanted to work more while only 10 percent wanted to work less, with the majority of workers (56 percent) satisfied with their work hours. German responses, on the contrary, were strikingly different from the ISSP: 44 percent of German workers wanted to work more, 7 percent wanted to work less, and 49 percent were satisfied and happier not to change their working hours (Katona et al. 1971: table 9-5). On net, the survey results suggest that Germans had a greater desire to work than Americans - the net balance favoring work was 24 percentage points in the U.S. case and 37 percentage points in the German case - indicating that at least in the 1960's, German attitudes toward work were similar to American attitudes today. The fact that Germans would choose to work more hours when their incomes were lower than American incomes in the 1960's fits nicely with standard income effects in labor supply. The fact that Germans have reduced their desire for hours as their incomes have risen in the 1970's and 1980's is also consistent. What is odd is that in the 1990's, with comparable living standards, Americans and Germans are so different and so extreme in their preferences for work.

\section{TOWARDS AN EXPLANATION OF THE WORK HOURS GAP}

Documenting the fact that differences exist in the hours and preferences of German and American workers naturally leads to the question of why these differences occur. Are they due to differences in taxation that affect marginal wages or public provision of goods that has an income effect on workers? Are differences a 
function of cultural attitudes or are they related to institutions? Is there something inherently different in the structure of pay and the system of rewards in the two countries? In this section we explore the plausibility of two alternate explanations for the gap-a standard labor supply interpretation stressing differences between the two countries in the value of an extra hour of work, and a more subtle supply explanation stressing differences in the structure of pay and the rewards to effort in the two countries.

\section{A Standard Supply Explanation}

Several facts favor a labor supply interpretation of the work hours and preference gap differences between U.S. and German workers. First, average (and marginal) tax rates for a typical German production worker are roughly 30 percent higher than tax rates for a typical U.S. production worker. ${ }^{17}$ This difference implies that the rewards to working extra hours are smaller in Germany even at the same rate of pay. Second, social income (welfare transfers, health care, unemployment insurance, subsidized college and university education, and apprenticeship programs) is more generous in Germany than in the U.S., which should increase demand for leisure through the income effect. ${ }^{18}$

Turning to changes over time, the rise in real income in Germany over the last twenty-five years should, according to standard theory, encourage greater leisure over work. By contrast, real earnings have not grown in the U.S. over much of the same period, and have fallen for large portions of the working population, ${ }^{19}$ which might necessitate working harder to maintain a given living standard. In the 1980's, significant tax changes in the U.S. substantially reduced the progressivity of federal taxes, possibly encouraging preferences for additional work among large segments of middle-income American workers. ${ }^{20}$

Unfortunately, the ISSP data do not allow us to estimate the labor supply parameters needed to test the standard supply model. The hourly earnings variable in ISSP is constructed from information on annual earnings and weekly hours and is therefore not independent of reported hours worked. The annual earnings data are, moreover, reported in ranges of annual earnings, leading to measurement error of actual earnings, with resultant negative bias in estimates of the effects of hourly pay on hours worked. Finally, there is no data in the ISSP on assets or wealth.

Given these problems, we examined the possible effect of income and substitution effects on hours differences across countries as follows. We first estimated reduced form hours equations of the form:

$$
\ln \text { Hours }=f(\text { Country, Demographics, Union Status })
$$

where country is the country-specific dummy variable controls; the demographic variables include controls for gender, marital status, prime age working age status, household size, and education; and union status is equal to 1 if the individual is a union member and zero otherwise. Preferences for work as revealed by qualitative 
responses to a set of work-related questions were included in certain specifications of the model. ${ }^{21}$ The coefficients from the individual country specific dummy variables are then used to estimate an auxiliary regression of the form:

$$
\text { Country Dummy }=f \text { (Income, Hourly Earnings) }
$$

using the eight individual country dummy variables plus constant term from equation (2) above, and aggregate data on income and earnings within countries. Equation (3) tests the importance of income and earnings in explaining hours differences across countries abstracting from the effects of demographics and union density.

Ordinary least squares estimates of equation (2) are presented in Table 5.8 for all workers, male workers only, and full-time workers only for all of the countries in the 1989 ISSP. Column 1 includes country-specific dummies and shows that U.S. workers work an average of 6 percent more hours per week than do German workers, and work significantly more hours than workers in all other surveyed European OECD countries with the exception of Ireland. Note, however, that in these data the hours worked by Germans are not particularly low: the Netherlands, U.K. and Northern Ireland, and Norway have lower hours worked than Germany. These regressions are thus better attuned to treat the greater work time of Americans than the low work time of Germans. The addition of demographic information and union membership in column 2 does little to reduce the gap between the U.S. and other countries, nor between the U.S. and Germany. Column 3 adds a set of dummy variables that measure responses to several questions on attitudes toward work. These measures enter the equations in a complicated way that is not always consistent in later calculations. The most powerful and important variable is whether or not people say they work hard even if it interferes with their lives. Inclusion of these attitude variables reduces the differences in hours worked between U.S. and German workers, although not between U.S. and most other European OECD countries.

Columns 4-9 of the table perform the same analysis on a subsample of male (columns 4-6) and full-time (columns 7-9) workers. The coefficient estimates in columns 4 and 7 confirm that differences in usual weekly hours of work between U.S. and German workers are smaller among male workers and are larger among full-time workers. The addition of demographic controls and qualitative preferences reduces the difference between U.S. and German males in hours worked but not between the U.S. and other countries. The demographic and qualitative variables are less important in explaining differences in hours worked among full-time U.S. and German workers.

In sum, the Table 5.8 calculations show that some of the U.S.-German differences are associated with attitudinal or demographic differences bur that the big gap in hours between Americans and Western Europeans cannot be so explained.

Table 5.9 presents estimates from auxiliary regressions using the country specific dummy variables plus the constant in Table 5.8 as dependent variables, and 1989 


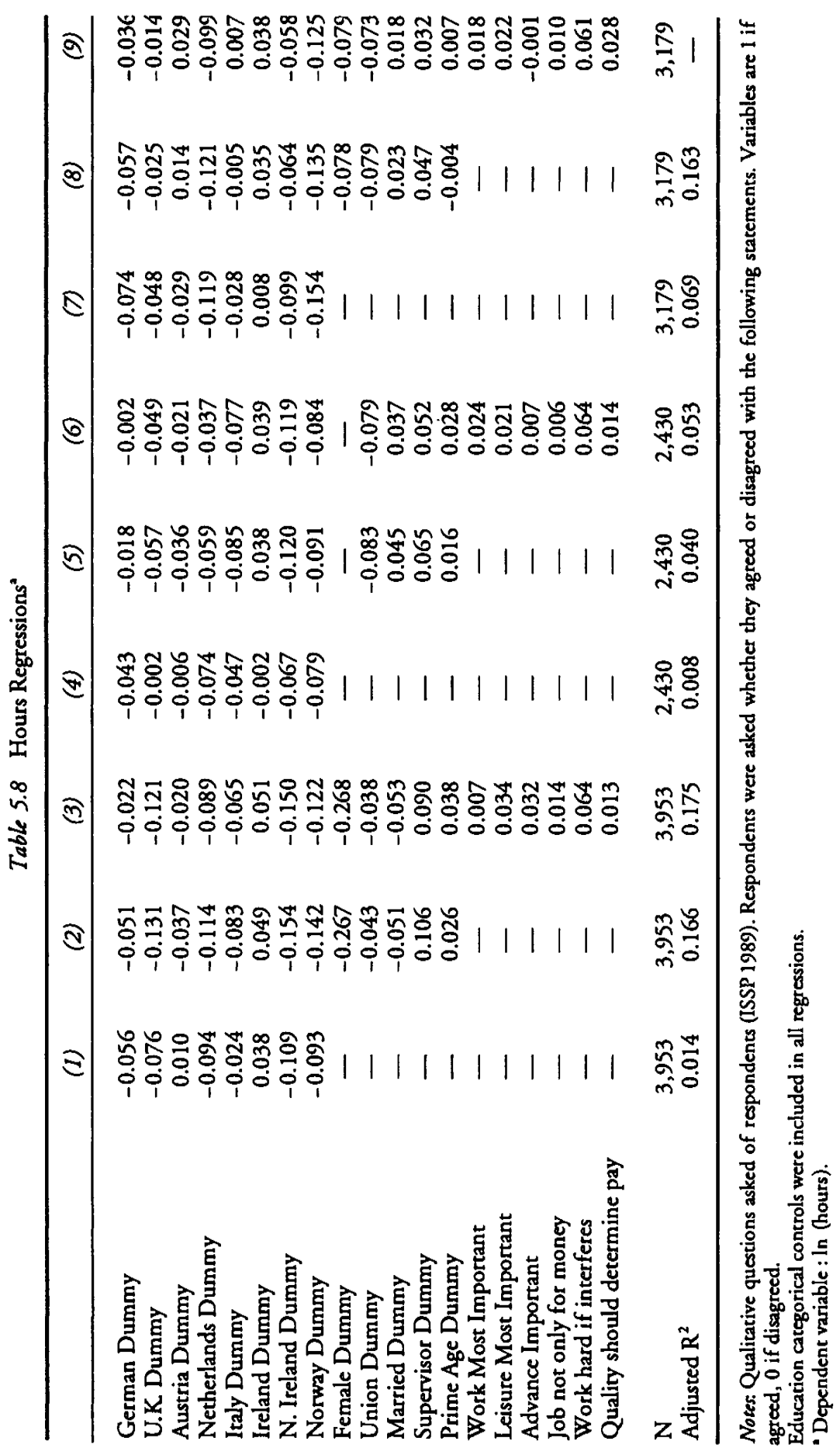


Table 5.9 Auxiliary Regressions

\begin{tabular}{lccc}
\hline & $\left(2^{\prime}\right)$ & $\left(5^{\prime}\right)$ & $\left(8^{\prime}\right)$ \\
& All Workers & Male Workers & Full-time Workers \\
\hline In Income & 0.084 & 0.055 & 0.031 \\
& $(0.102)$ & $(0.074)$ & $(0.085)$ \\
In Average Hourly Earnings & -0.004 & 0.022 & -0.128 \\
& $(0.166)$ & $(0.120)$ & $(0.139)$ \\
$\mathrm{R}^{2}$ & 0.111 & 0.085 & 0.174 \\
\hline
\end{tabular}

Sources: Aggregate Country Income data for 1989-OECD Historical Statistics, 1960-1990.

Aggregate Country Earnings data for 1989-ILO Yearbook of Labor Statistics, 1992

Notes. ${ }^{2}$ Dependent Variable: Country Dumny Coefficients from In hours Regressions.

Country Dummy Coefficient Variables are taken from Table 5.8 regressions by column number as indicated.

Number of Observations in each case is 9.

country-specific data on personal disposable income per capita (from OECD Historical Statistics) and average hourly wages (from ILO Yearbook of Labor Statistics). The auxiliary regressions offer no support for the idea that differences in In hours across countries are explained by differences in either mean hourly earnings or personal income, and therefore no support for the view that basic labor supply factors can readily explain these differences.

In sum, there remain substantial differences in hours worked across countries after accounting for demographics, preferences, and average wages and income. In the case of the U.S. and Germany at least, differences in attitudes toward work seem to matter in determining actual hours worked, although less so for full-time workers.

\section{Are Attitudes Toward Work Related to Incentives?}

Given the difficulties with estimating a labor supply model in the ISSP data, we consider next whether the information on preferences in the survey can be used to evaluate the importance of labor supply factors. Is there evidence that differences in preferences for work are explained by the incentives that affect labor supply?

To the extent that differences in the preferences of American and German workers reflect different marginal valuations of an extra hour of work, the impact of earnings on preferences should differ across countries. An extra hour of work in Germany should be valued less compared to an extra hour in the U.S., since Germany has relatively high taxes and generous public income. We can test this idea by estimating equations linking preferences for work to a set of country controls, and demographic and union controls and to hourly earnings, since measured earnings are exogenous in this specification. ${ }^{22}$ 
Results of the probit models using worker preferences are presented in Table 5.10 for all workers. The preference question asks workers (see Table 5.4) to indicate whether they would chose to work more hours at more pay, the same number of hours at the same pay, or fewer hours at less pay. Workers who say that they wish to work more hours receive a value equal to 1 , and all other responses receive a value of zero. The earnings variable obtains a significant negative coefficient in columns 2,5 , and 8 , indicating that for all the groups of workers, those with higher earnings are less likely to want to work more hours - an income effect. But the differences berween U.S.-German and U.S.-European preferences for longer work (column 1) are not consistently and uniformly muted by the inclusion of ln earnings, demographic, union status, and other qualitative controls (column 2). The country-specific interaction terms (column 3) are not significant, suggesting that differences in preferences are not related to differences in the marginal valuation of an extra hour of work as so measured. Columns 4-6 repeat the analysis for male workers, and columns 7-9 for full-time workers, with qualitatively similar conclusions in all cases. There is no support in the probits that U.S.-German differences in preferences for work are explained by earnings differences.

In addition to the regressions above, other factors make us wary of a standard labor supply interpretation of the U.S-German hours and preferences gap. First, although tax rate and social income differences favor reduced work effort in Germany relative to the U.S., they do not necessarily favor reduced work effort between German workers and workers in many other European countries with similar taxation and welfare state benefits. Second, estimates of rather modest wage, wealth, and marginal tax effects in determining U.S. vacations (Green and Poterban 1987) suggest that marginal decisions are unlikely to explain large differences between work effort in the United States and in Germany and Europe.

\section{Hours Differences and Earnings Inequality}

How then are we to explain sizable differences in the preferences and work hours of American and German workers? In this section we take a different approach to this question, focusing not on differences in the average valuation of an extra hour of work, but instead on differences in the distribution of rewards that determine the average.

In the decentralized U.S. labor market, which produces relatively high earnings inequality among workers, the rewards to greater effort are large and the penalties to slack substantial. By contrast in the highly centralized German labor market, which produces relatively low earnings inequality across workers and imposes institutional laws that make employee dismissal difficult, the rewards and penalties to greater effort are presumably less extreme. If earnings inequality allows for a system of rewards that encourages working harder, then the U.S.-German hours and preference gap may represent different payoffs to effort which are not relared to differences in mean (tax and social income adjusted) earnings but are instead 


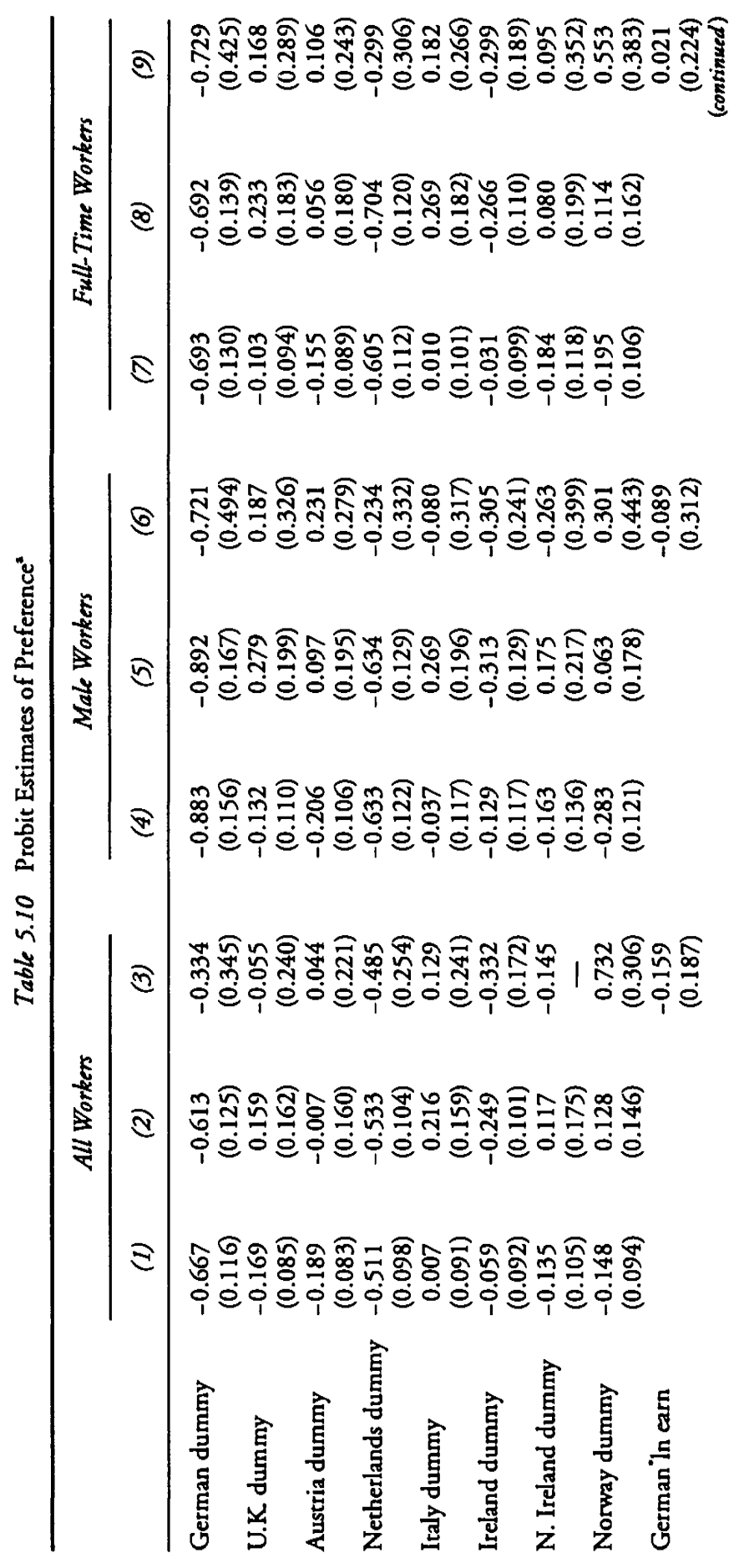




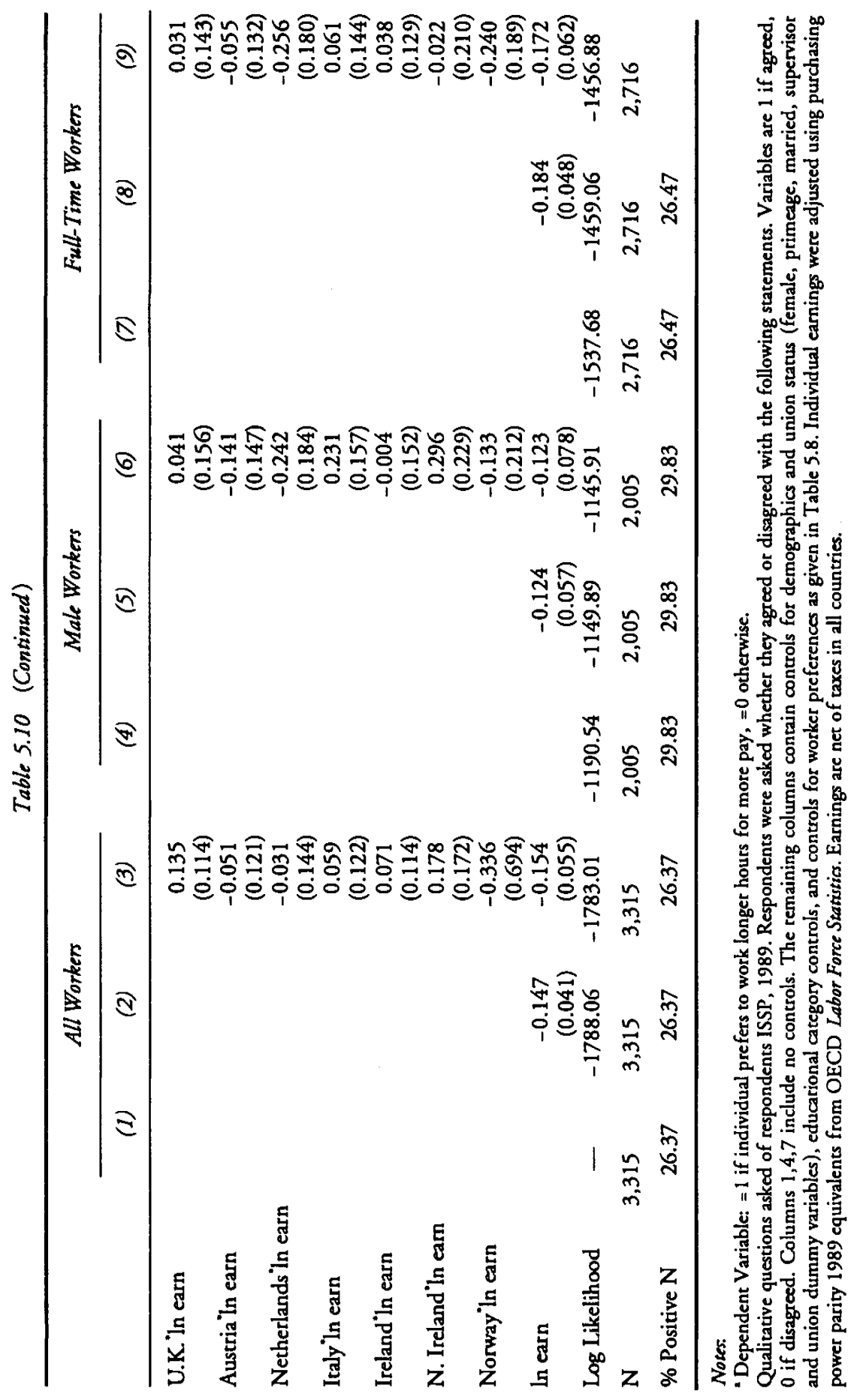


related to differences in earnings variance among workers. Put differently, the U.S. wage determining system may be closer to a tournament or piece rate wage system - you work hard to advance, to keep the good job, to keep from falling into a shallow safety net-whereas the German wage determining system and social benefits system is closer to a guaranteed annual income.

Our notion that it is the difference in the payoff from working many hours or working few hours or working more or less hard that morivates people to work many hours diverges from normal labor-supply analysis, but is consistent with the basic economics of incentives. It suggests that the "right" substitution variable in explaining hours is not the wage (holding fixed for income) but the difference in lifetime earnings from working more hours or not working more hours, where liferime earnings would reflect advancement, the loss of income from loss of job, etc. From this perspective, inequality of earnings is a proxy measure of the potential gain/loss from working more, and hours worked should be longer the greater the level of earnings inequality.

Table 5.11 presents statistics on earnings and hours to gauge the plausibility of such a link. Column 1 of the table lists the mean of In hourly earnings in dollars in each country (using 1989 purchasing power equivalents). Column 1' then ranks each country according to the pay of its workers (with a rank of 1 indicating the highest pay country and a rank of 9 indicating the lowest pay country). Columns 2 and 2 ' do the same thing for the variance of In earnings across countries. Finally columns 3 and $3^{\prime}$ list mean weekly hours and rank respectively. As is clear from the table, differences in hours worked across countries do not appear to be related to differences in mean earnings, but do appear to be related to differences in earnings inequality. For example, four countries with the highest hourly earnings

Table 5.11 Relationship between Hours Worked and Earnings

\begin{tabular}{lcccccc}
\hline & $(1)$ & $\left(I^{\prime}\right)$ & $(2)$ & $\left(2^{\prime}\right)$ & $\begin{array}{c}\text { (3) } \\
\text { Mean } \\
\text { Weekly } \\
\text { Hours }\end{array}$ & Rank \\
& $\begin{array}{c}\text { Mean } \\
\text { In(Eam) }\end{array}$ & Rank & $\begin{array}{c}\text { Variance } \\
\ln (\text { Eam) }\end{array}$ & Rank & & \\
\hline U.S. & 2.054 & 4 & 0.820 & 2 & 46.712 & 2 \\
Germany & 2.205 & 1 & 0.236 & 8 & 42.589 & 7 \\
U.K & 1.912 & 5 & 0.338 & 5 & 44.425 & 5 \\
Austria & 1.584 & 8 & 0.386 & 3 & 45.975 & 3 \\
Netherlands & 2.070 & 3 & 0.275 & 6 & 41.506 & 8 \\
Italy & 1.849 & 6 & 0.363 & 4 & 45.070 & 4 \\
Ireland & 1.103 & 9 & 1.048 & 1 & 47.849 & 1 \\
N. Ireland & 1.845 & 7 & 0.261 & 7 & 42.779 & 6 \\
Norway & 2.201 & 2 & 0.161 & 9 & 38.765 & 9 \\
\hline
\end{tabular}

Source. ISSP 1989

Notes:

' Data pertain to usual hours worked for full-time workers (working $35+$ hours).

Individual earnings were adjusted using purchasing power parity 1989 equivalents from OECD 


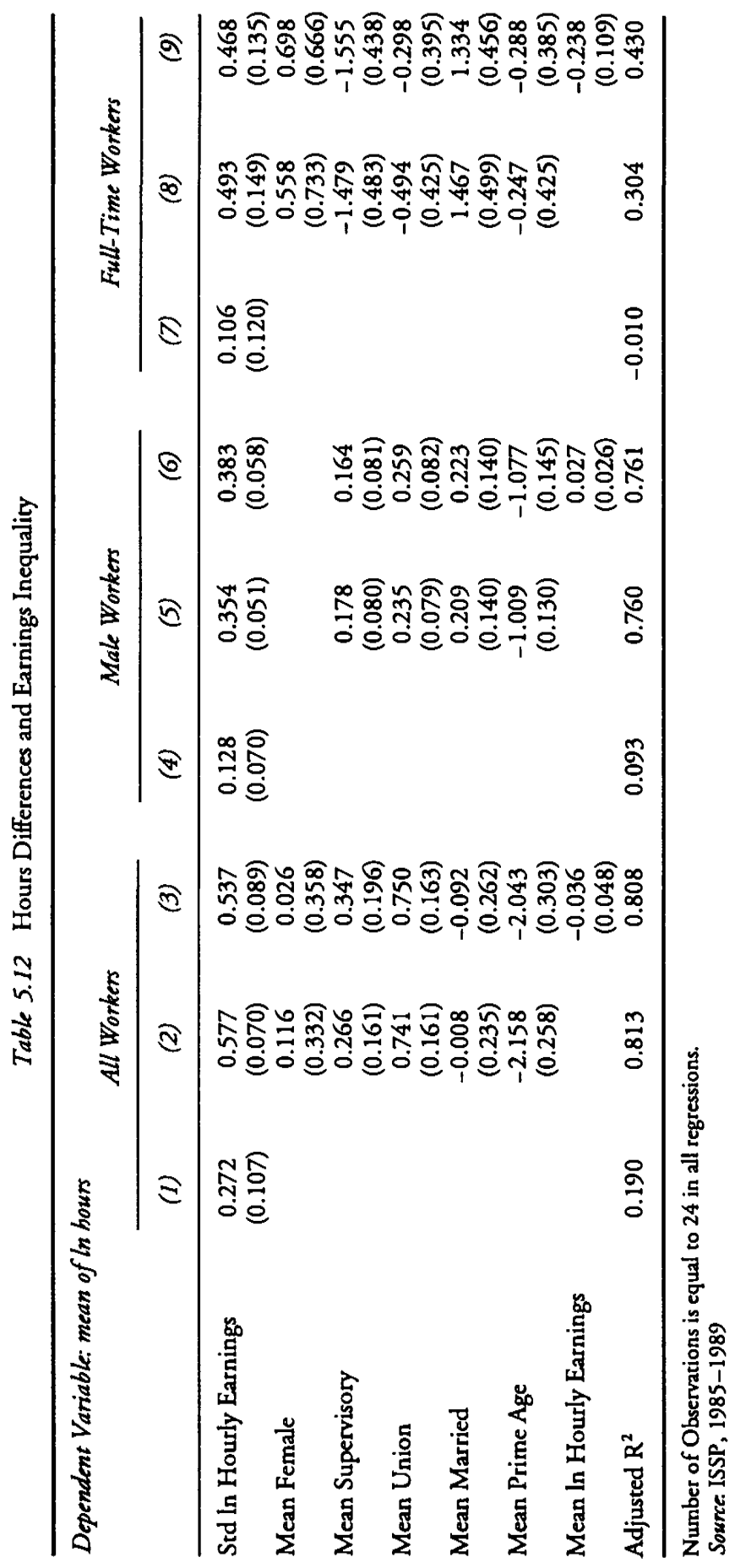




\section{LINDA BELL, RICHARD FREEMAN}

inequality-Ireland, the U.S., Austria, and Italy-also rank as the top four in hours worked, with identical hours worked and inequality rankings. Similarly, the four countries with the lowest inequality ranking-Norway, Germany, Northern Ireland and The Netherlands - have the lowest work hours, again with identical hours and inequality rankings. The only exception to this pattern of matching seems to be in Austria and Northern Ireland.

The Table 5.11 rankings do not control for demographic differences and contain limited information about the relationship between hours and earnings inequality. In order to control for demographics and union density while evaluating the link berween hours worked and earnings inequality, we pool information across countries from the 1985-1989 ISSP, and regress mean In hours on the standard deviation in earnings in each country and a set of demographic and union density controls (limited by availability in all years). The results of these regressions are given in Table 5.12. The table shows a statistically significant link between hours worked and earnings inequality which is independent of differences in demographics (column 2) and mean earnings (column 3 ) and is robust for a subsample of men (columns 4-6) and full-time workers (columns 7-9).

In sum, the results offered here are consistent with the idea of a link between hours worked and earnings inequality across countries, and suggest that American workers may work more hours and German workers may work less hours because of differences in the structure of rewards and penalties for work effort in the two countries.

\section{CONCLUSIONS}

This chapter has documented several facts of note. First, significant differences exist in the hours worked by American and German workers. Our estimates suggest that in 1989-1990, German workers worked between 10-15 percent fewer hours on an annual basis than did U.S. workers. Large differences between U.S. and German work hours appear to be driven, at least in part, by the fact that U.S. workers work comparatively long hours relative to workers in other OECD European countries, and that German workers work relatively short hours. Forces at work in Germany today suggest that if anything, differences in the actual hours worked between Americans and Germans will widen in the 1990's.

Second, sizable differences exist in the preferences of U.S. and German workers for work. Responses to a series of qualitative questions from a number of surveys paint a clear picture-Americans have a greater desire for work than do Germans. Although a majority of American workers are satisfied with their working hours, far greater numbers would prefer more over less work if given the choice. Among Germans the opposite preferences prevail, with greater shares of German workers preferring less over more work. Although American workers are extreme among surveyed OECD countries in their desire for work, Germans are equally extreme in their desire for leisure. The preference for work gap between Americans and Germans, like the hours gap, is wide for these reasons. 
Third, differences across countries in hours worked are not related statistically to income and earnings, and differences in preferences do not represent distinct responses to earnings across countries.

Fourth, we present empirical evidence that workers work longer hours in countries with high earnings inequality and shorter hours in countries with low earnings inequality, that suggests a different sort of labor supply interpretation of the U.S.-German work hours gap. In Germany the payoffs to working more may be limited by a centralized system that encourages uniformity in pay. In the U.S. high earnings inequality may be responsible for the view that the harder Americans work and the harder they say they want to work, the more likely will the unequal system reward their good efforts.

\section{ACKNOWLEDGMENTS}

We thank John LaBarre for providing extremely helpful research assistance.

\section{NOTES}

1 For example, the 1990 IG Metall agreement specifies an agreed weekly hours reduction to 36.0 effective January 4,1993 and a further reduction to 35.0 hours effective January 10, 1995. For more detailed information on these agreements see Bosch (1992).

2 This report calls for considerable greater work effort on the part of Germans. Chancellor Kohl has stated "With ever shorter working hours, rising wage costs, and ever longer holidays, our competitiveness is in danger" (quoted in Financial Times Survey of Germany, October 25, 1993: 1).

3 Given the higher female participation in the United States, American workers actually work nearly as many hours as the Japanese per adult person. Similarly, although Luxembourg ranks slightly above the United States in annual hours according to the Germany Employers' Association data, it lies below the U.S. annual hours after adjustment for the higher employment to population rate in the United States.

4 The precise period when U.S. and German hours crossed varies depending on whose estimated hours worked one uses. All estimates that we know of suggest however that the crossover occurred no earlier than the 1970's, and moreover, all estimates indicate a substantial widening of the gap after 1983.

5 In addition, there were modest differences in unemployment rates (OECD Employment Outlook 1992) which would effect the uniformity of the annual estimated hours across the working population.

6 A further refinement in hours comparisons is also possible: estimating lifetime hours worked by taking account of years of retirement and life span. We have not made estimates of lifetime hours worked.

7 Note that the annual hours in column 1 provide estimates of the ln differential in U.S. and German hours of 0.15 , and are therefore consistent with the OECD data calculated adjusted differences for all workers.

8 The data are establishment survey equivalent data provided by European sister employer associations to the German BDA. Estimates of German work hours and vacation time are roughly consistent with OECD data, although the differences between countries in holiday time are somewhat larger in this source. These differences presumably reflect actual differences caused by the sample of full-time as opposed to all workers. 


\section{LINDA BELL, RICHARD FREEMAN}

9 The hours question asked of U.S. and German workers were not identical. The question was phrased to U.S. workers as, "How many hours did you work last week, how many hours do you usually work a week, at all jobs?" The same question was phrased to German workers as, "How many hours per week do you normally work in your main job, including overtime?" Two possible sources of noncomparability arise in this context. First, German workers hours explicitly include normal overtime hours, where U.S. workers hours should, but may not. Second, German hours should correspond to the main job and not all jobs, whereas the U.S. hours question explicitly correspond to all jobs. In order to correct this difference reported second job hours are added to the hours of German workers who report a second job, and it is this adjusted figure that is used in the regression analysis.

10 The difference is due to the fact that the U.S. hours distribution is more variable and a greater percentage of U.S. workers (24 percent) are working less than full-time (35 hours per week) than German workers (19 percent).

11 The large difference between the hours of German and American self-employed workers is due in part to the fact that the U.S. distribution of self-employed hours is far more variable (the standard deviation of hours is 17.08 in the U.S. and 10.40 in Germany). For example, when we consider the preferences of full-time self-employed in the two countries, the hours differences narrow-German full-time self-employed work 52.5 hours and Americans work 50.4 hours.

12 Note also the U-shape to the relation between hours worked and preference for work among Americans. The proportion of Americans who want to work more hours compared to the proportion who want to work fewer hours falls as hours worked rises from less than 35 to $35-40$, and then rises after 45 plus hours.

13 An interesting test of the meaning of the hours preference question would be to isolate the frequency of behavioral changes in people who said they preferred more/fewer hours in ensuing periods. The group rotation structure of the CPS would permit such an analysis to be conducted; although we have not evaluated this issue.

14 Note that this differs from the ISSP result in Table 5.4. Given the much larger CPS than ISSP sample and the law of diminishing marginal value, we find this pattern more believable. Americans may be workaholics, but when they reach 60 plus hours, enough work seems to be enough work.

15 It also has a problem because it poses a situation in which the marginal rate of substitution of goods for leisure is not equal to the wage. People would do better with some mixture of a higher wage and change in hours.

16 The U.S. question was asked in 1966; the German question in 1968.

17 For example, the average tax rate for a typical German production worker in 1991 was 37 percent (including social security contributions). The average tax rate for a typical American production worker was 27 percent in 1991. For more details on the institutional structure of the tax codes in each country see OECD (1990).

18 For example, Esping-Anderen's (1990) "de-commodification" scores for the welfare programs of various countries gives the U.S. the lowest score-considerably below that for Germany. Empirically, the countries with high "de-commodification" indices (most notably Sweden, Norway, Netherlands, and Sweden) have low hours per employee in the OECD data, while the three countries with the least "decommodification" scores (the U.S., Japan, and Canada) rate very high in hours worked per employee.

19 A substantial literature has arisen charting the course of real earnings stagnation in the U.S. since 1970. See Levy and Murname (1992) for an excellent summary of the literature.

20 Major tax reform legislation was passed in 1981 and 1986. For details on these changes see Pechman (1991). 


\section{WHY DO AMERICANS AND GERMANS WORK DIFFERENT HOURS?}

21 Questions asked respondents to agree or disagree with the following statements:

(a) work is the most important activity;

(b) leisure is not important;

(c) advancement in my job is important;

(d) I work at my job not only for the money;

(e) I work hard even if it interferes with the rest of my life; and

(f) quality should determine pay

Variables were coded as $=1$ if respondent agreed with the statement and $=0$ otherwise.

22 Using workers' responses to questions about their preferences for work as opposed to actual hours worked in an hours regression eliminates the endogeneity between annual weekly earnings and hours discussed above, and therefore allows us to test the importance of earnings differences in preferences for work.

\section{REFERENCES}

Bosch, G. (1990) "From 40 to 35 Hours: Reduction and Flexibilization of the Working Week in the Federal Republic of Germany," International Labour Review 129, 5.

(1986) "The Dispute over the Reduction of the Working Week in West Germany," Cambridge Journal of Economics 10: 271-290.

European Economic Community (1991) European Economy, March.

Esping-Andersen, G. (1990) The Three Worlds of Welfare Capitalism, Princeton: Princeton University Press.

Green, F. and Poterban. M. (1987) "Vacation Time in the U.S. and Europe," paper delivered at EMRU Study Group, April 1987.

Katona, G., Strumpel, B. and Zahn. E. (1971) Aspirations and Affuence: Comparative Studies in the U.S. and Western Europe, New York: McGraw-Hill.

Levy, F. and Murnane, R. (1992) "U.S. Earnings Levels and Earnings Inequality: A Review of Recent Trends and Proposed Explanations," Journal of Economic Literature XXX, 3, September.

OECD (1990) Historical Statistics 1960-1989.

(1992) Economic Outlook, July.

The Tax Benefit Position of Production Workers, July.

Owen, J. (1986) Working Lives: The American Work Force Since 1920, Lexington, MA: D.C. Heath.

(1988) "Work-Time Reduction in the U.S. and Western Europe," Monthly Labor Review, December: 51-54.

(1989) Reduced Working Hours: Cure for Unemployment or Economic Burden?, Baltimore: Johns Hopkins Press.

Pechman, J. (1988) World Tax Reform, Washington: Brookings Institution.

Shank, S. (1986) "Preferred Hours of Work and Corresponding Earnings," Monthly Labor Review, November: $40-44$. 